\title{
Impact of the Quality Costs applied in Automotive and Metal-Mechanical Manufacturing SMEs in the North of Aguascalientes. Municipality of Rincon de Romos
}

\section{Impacto de los costos de calidad aplicados en las PYME de fabricación automotriz y metalmecánica en el norte de Aguascalientes. Municipio de Rincón de Romos}

VAZQUEZ-GUTIERREZ, Rosa Inés †*, FLORES-AGUILAR, Mauricio y NÚÑEZ-MONTALVO, Juan Manuel

\section{Universidad Tecnologica del Norte de Aguascalientes}

ID $1^{\text {st }}$ Author: Rosa Inés, Vazquez-Gutierrez / ORC ID: 0000-0001-8774-7737, Researcher ID Thomson: X-2867-2018, CVU CONACYT ID: 529498

ID 1er Coautor: Mauricio, Flores-Aguilar / ORC ID: 0000-0003-0846-3803, Researcher ID Thomson: X-2169-2018, CVU CONACYT ID: 687471

ID 2do Coautor: Juan Manuel, Núñez-Montalvo / ORC ID: 0000-0003-1053-8843, Researcher ID Thomson: X-3186-2018, CVU CONACYT ID: 260539

DOI: $10.35429 / J Q S A .2019 .18 .6 .16 .24$

\begin{abstract}
This research is the result of 4 investigations carried out in the northern region of Aguascalientes. The municipalities on which this research is based are Aguascalientes, San Francisco de los Romo, Rincon de Romos, and Jesús María. The objective of this study is to investigate the costs incurred by companies in carrying out their operations in the municipality of Rincon de Romos. The realization of this research allows us to know the costs incurred by these surveyed companies in order to know in what percentage the highest quality costs applied, whether in prevention costs, evaluation costs, internal failure costs and external failure costs.
\end{abstract}

Quality costs, Internal failure costs, External failure costs, Prevention costs, Evaluation costs

\begin{abstract}
Resumen
Esta investigación es el resultado de 4 investigaciones realizadas en la región del norte de Aguascalientes. Los municipios en los cuales se basa esta investigación son Aguascalientes, San Francisco de los Romo, Rincon de Romos, y Jesús María. El presente trabajo tiene como objeto investigar cuales son los costos en los cuales las empresas incurren al realizar sus operaciones en el municipio de Rincon de Romos. La realización de esta investigación permite conocer cuáles son los costos en los que incurren estas empresas encuestadas y clasificarlos en costos de prevención, costos de evaluación, costos de fallas internas o fallas externas.
\end{abstract}

Costos de calidad, Costos de fallas internas, Costos de fallas externas, Costos de prevención, Costos de evaluación

\footnotetext{
* Correspondence to Author (email: rosa.vazquez@utna.edu.mx)

$\dagger$ Investigador contribuyendo como primer autor.
} 


\section{Introduction}

This report presents an analysis of the situation of quality costs incurred by SMEs in the municipality of Rincon de Romos.

The companies that were explored in this municipality were balconies and metal mechanic workshops that are dedicated to the transformation of metals in the simplest forms, such as the creation of windows, the machining of metal parts, machinery or more processed parts.

The investigation is divided into six areas:
a) Leadership
b) Strategic approach.
c) Focus on markets and customers.
d) Management of people.
e) Quality Costs
f) Process management

The Costs of Quality are classified as:
a) Prevention costs
b) Evaluation costs
c) Internal failure costs
d) External failure costs

Then the results of the survey applied to a sample of 13 companies from a universe of 36 companies that correspond to $30 \%$ metalmechanical branch in this municipality according to the DENUE 2015 of INEGI are shown.

This project benefits the automotive industry and mechanical metal because it allows us to know what are the strengths and weaknesses in the application of quality costs, as well as it allowed us to know our University, UTNA, which are the courses that it can offer on these topics of quality in order to strengthen SMEs in the region.

This research is of relevant importance since the quality applied in the companies is required to be able to satisfy the needs of the clients and to be able to maintain in the market.

\section{Methodology}

According to Hernández Sampieri (2010) the study that was applied was a "Quantitative Exploratory" study where a data recovery tool, survey type, will be used.

\section{Sampling}

The type of sampling that will be carried out will be stratified, where the total population of each of the municipalities in different strata is divided. The advantage of this type of sampling is that it tends to ensure that the sample adequately represents the population based on selected variables. It also allows obtaining more precise estimates and its objective is to obtain a sample that is as similar as possible to the population in terms of the stratifying variable (s).

The result was a sample of 13 companies from a universe of 36 companies registered in the DENUE 2016 of the INEGI

\section{Background}

Quality costs represent the difference between the actual costs of a product or service and the reduced cost if it had not had the possibility of having a service below the standards, product failures, or defects in its manufacture.

They can be classified as observable or hidden, the observables are those found in the accounting records of an organization, the hidden costs are the opportunities that those of poor quality. All quality costs are observable and should be available in the accounting records, the hidden costs in the external failure category.

These costs can be important and should be estimated, although not easy, for which three methods are used.

1. The multiplier method.

2. The market research method.

3. The quality loss function of Taguchi.

The market research method is the one that will be carried out, this is used to evaluate the effect of poor quality. The surveys applied are based on questions elaborated from the classification of the four types of quality costs that are explained below. 


\section{Prevention cost:}

They are the costs of all activities specifically designed to prevent quality failures in products or services. For example:

- $\quad$ Review of new products.

- Quality planning (manuals, procedures, etc.)

- $\quad$ Evaluation of supplier capacity.

- Efforts for improvement through teamwork.

- $\quad$ Continuous improvement projects.

- $\quad$ Education and quality training.

\section{Evaluation cost:}

They are the costs associated with the activities of measuring, evaluating and auditing the products or services to ensure their conformation to quality standards and performance requirements. For example:

- Inspections with the supplier and on receipt.

- Tests and inspections in process and to the finished product.

Audits to the product, process or service.

- Calibration of test and measurement equipment.

Costs of test materials.

\section{Internal failure cost:}

They are the costs resulting from products or services that do not conform to the requirements or needs of the client, before the product is shipped or when the service is performed. For example:

\footnotetext{
- Waste

- Re-jobs

- Re-inspection and repetition of tests

- $\quad$ Review of non-conforming materials

- $\quad$ Reduced price for reduced quality
}

\section{Internal failure cost:}

They are the costs resulting from products or services that do not conform to the requirements or needs of the client, after the delivery of the product or during and after the completion of the service. For example:
$-$

- Customer returns

- Guarantee

- $\quad$ Campaigns for defective products

\section{Results}

\section{Leadership}

In Rincon de Romos, the companies surveyed stated that they had vision, mission, values and objectives in $31 \%$ while $69 \%$ of them did not count on it.

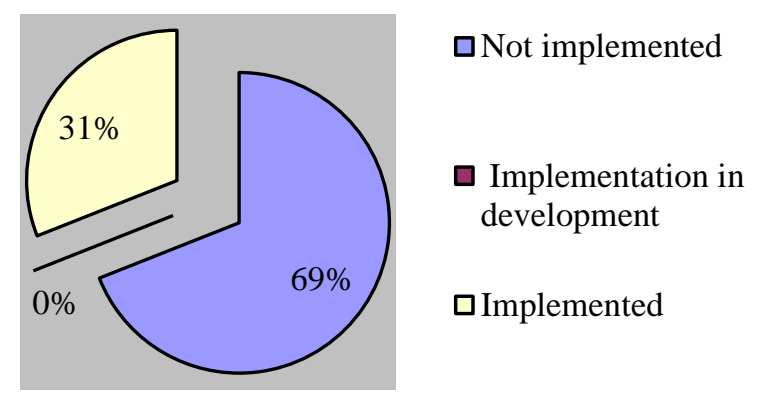

Graphic 1 Implementation of the mission, values and strategic objectives

These companies, $77 \%$ of their members of the company know the responsibilities and actions they must perform while $23 \%$ said they do not have a procedure for this.

Another aspect that was evaluated is if the companies focus on the creation and innovation of new products, the companies responded by $77 \%$ that they have implemented this aspect, while $8 \%$ seek to develop it and $15 \%$ do not count on it.

Also of these companies, only $8 \%$ have a policy for environmental aid, another $8 \%$ seek to develop it and $84 \%$ do not count on it.

None of the companies is certified with ISO 14000 , only $8 \%$ seek this certification and the rest, as mentioned, is not certified.

\section{Strategic approach}

In the area of strategic approach, these companies have a process to consider the expectations of markets and customers by $23 \%$; while $15 \%$ are seeking to implement it and $62 \%$ have not implemented it. 


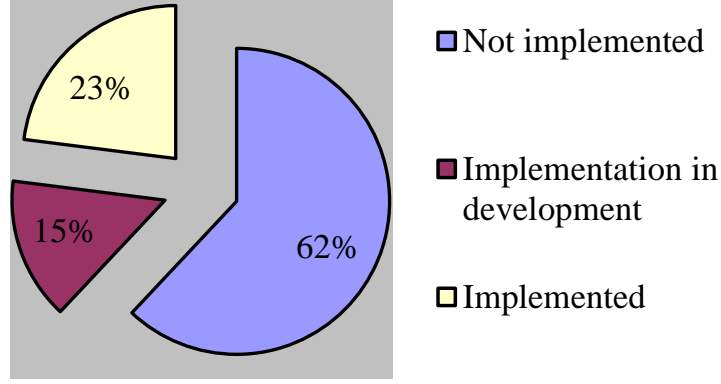

Graphic 2 In Rincon de Romos 23\% of the companies do not have a planning process where they limit their competitive scenario and consider the expectations of the markets and customers.

These companies have a $31 \%$ planning process where shareholders' aspirations are considered, while $69 \%$ said they did not count on it. In addition, in Rincon de Romos, companies have a planning process that considers the capacities of the company and its workers by $31 \%$, while $15 \%$ are seeking to implement it and $54 \%$ have not implemented it.

These companies also have a planning process where the capacities of their suppliers are considered in $38 \%$, although $62 \%$ do not.

\section{Focus on markets and clients}

In the area of market and customer focus, 38\% have procedures where the company determines the markets where their most important customers will be, $15 \%$ seek to implement this procedure and $46 \%$ do not have it implemented. $15 \%$ of the companies consulted have a method to investigate what are the requirements of customers according to the products and / or services offered, while $8 \%$ of companies seek to implement this method and $77 \%$ do not implemented.

In Rincon de Romos, $8 \%$ of the companies consulted seek to implement a method of market research to detect new businesses, $92 \%$ do not.

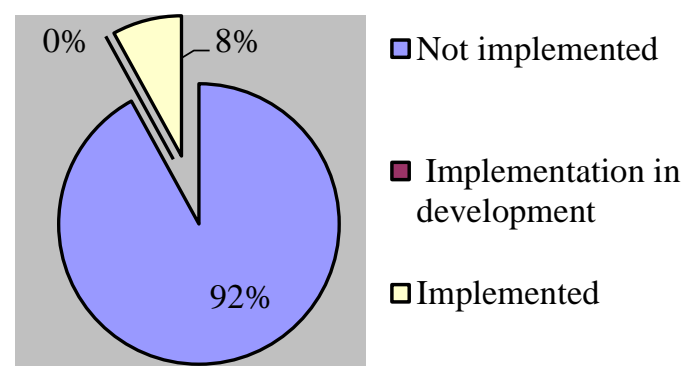

Graphic 3 Method of market research to detect new businesses

ISSN 2410-3438

ECORFAN® All rights reserved
$38 \%$ of the companies analyzed have a formal procedure to ensure that complaints and claims are resolved in a timely manner, $8 \%$ seek to implement it and $54 \%$ do not.

\section{Management of people}

In the section on people management, $46 \%$ of companies plan to select their workers, $15 \%$ seek to implement this procedure, while $38 \%$ do not.

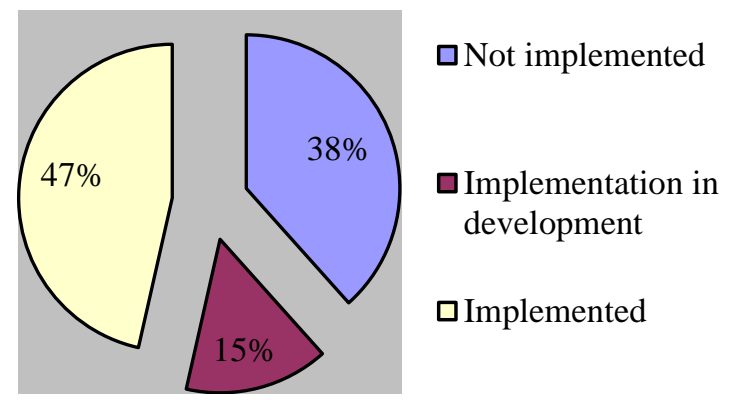

Graphic 4 En Rincon de Romos el 46\% de las empresas consultadas tiene en proceso de implementación la selección de sus trabajadores

In Rincon de Romos, $46 \%$ of companies plan the training and development of their workers, while $23 \%$ seek to implement it and $31 \%$ have not implemented it.

In addition, $31 \%$ of these companies communicate clear goals and work assignments that guide the staff in their action, $23 \%$ of these companies seek to implement it and $46 \%$ have not implemented it.

$77 \%$ of companies do not have a remuneration policy and structure that covers all jobs that ensure the quality and competitiveness of the company, while $23 \%$ do so.

Only $8 \%$ of the companies consulted have methods of recognition and reward for the achievement of objectives that ensure the quality and competitiveness of the company, $15 \%$ wish to implement it, while $77 \%$ have not implemented it.

$8 \%$ of companies seek to implement a safety and hygiene department and 92\% do not count on it.

$92 \%$ of companies do not have OHSAS 18001 certification, only $8 \%$ seek to implement it. 


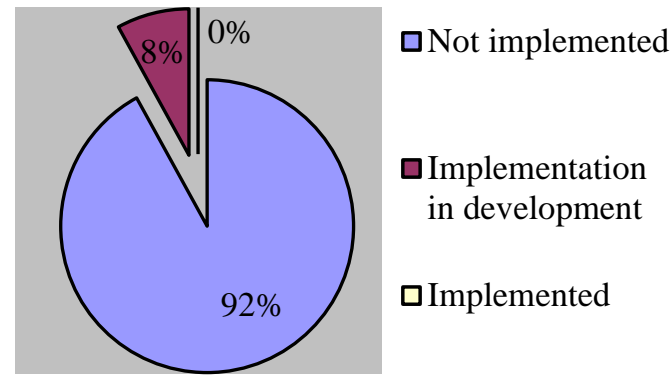

Graphic 5 Implementation of the OHSAS system

\section{Quality costs}

This item was divided into 4 stages for its investigation, then the results of each of these stages are explained.

\section{Prevention costs}

The companies of Rincon de Romos, in $77 \%$ of these inspect the material when it arrives at the plant, $8 \%$ seek to implement this process and $15 \%$ do not have it implemented. Of these companies, $15 \%$ have plant distribution, while $8 \%$ seek to implement it and the rest, $77 \%$ have not implemented it.

On the other hand, of these companies only $31 \%$ have 5 'S application, while $23 \%$ seek to implement it and $46 \%$ do not count on it.

\section{Regarding Quality Management} Systems, only 8\% have a QMS applied, while $92 \%$ do not have it. This is reflected because again $8 \%$ of the companies consulted use verification sheets and $92 \%$ do not.

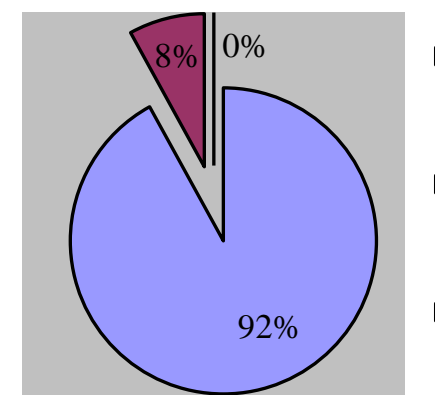

$\square$ Not implemented

Implementation in development

口Implemented

Graphic 6 Implementation of Quality Management Systems

The same happens with the formats implemented, $8 \%$ have them and $92 \%$ do not have them. While $38 \%$ have procedures in place, $15 \%$ seek to implement them and $46 \%$ do not have them. Likewise, only $8 \%$ have a quality manual implemented, while $92 \%$ do not count on it.
$8 \%$ of these companies have a recruitment area, while $92 \%$ do not count on it.

It was also mentioned that $8 \%$ of the companies consulted are developing how to have trained personnel to recruit, while the remaining $92 \%$ are not considering it.

In the area of internal quality audits, $8 \%$ are seeking to implement this tool, while $92 \%$ do not have this.

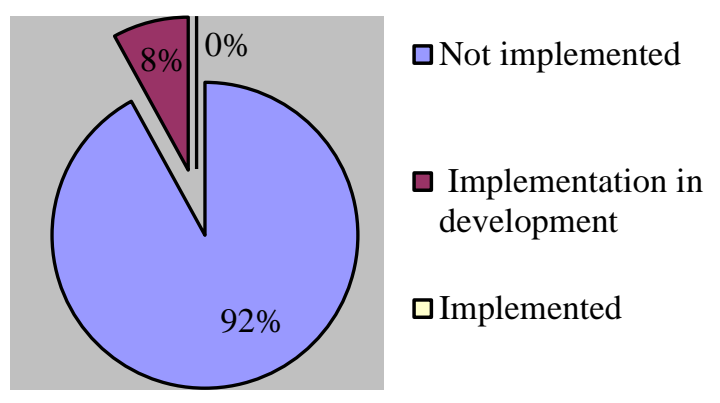

Graphic 7 Use of Internal Quality Audits

The same happens with external quality audits where $8 \%$ said they have this tool in development and the remaining $92 \%$ do not use this tool.

Another questionable tool was whether there is a product design area, where $8 \%$ say they count on it, while $92 \%$ do not use it.

These companies, said that $31 \%$ have a metrology area, while $8 \%$ seek to develop this area and $62 \%$ do not have it.

Also questioned about the application of quality circles within each company, $8 \%$ mentioned that if you use this tool, while $92 \%$ does not apply it.

These companies stated that they have continuous improvement projects in $23 \%$, however $77 \%$ do not count on it.

$8 \%$ implements the Kaizen day, while $92 \%$ does not apply it. $100 \%$ of the companies consulted said they did not have a marketing department. Likewise, $100 \%$ of these companies do not conduct marketing research.

In addition, $8 \%$ mentioned that they have planned that their vendors with whom they have some type of certification, while $92 \%$ have not considered it.

VAZQUEZ-GUTIERREZ, Rosa Inés, FLORES-AGUILAR, Mauricio y NÚÑEZ-MONTALVO, Juan Manuel. Impact of the Quality Costs applied in Automotive and Metal-Mechanical Manufacturing SMEs in the North of Aguascalientes. Municipality of Rincon de Romos. Journal of Quantitative and Statistical Analysis. 2019 


\section{Evaluation costs}

In Rincon de Romos, the companies consulted said that $54 \%$ of them carry out inspections with the supplier, $8 \%$ seek to implement this procedure and $38 \%$ do not count on it.

These companies mentioned that $69 \%$ of them have a raw material inspection before going into production, $8 \%$ seek to implement this procedure and $23 \%$ do not count on it.

On the other hand, they mentioned that $46 \%$ of these companies have costs in returning damaged raw materials, while $54 \%$ said they do not generate these costs.

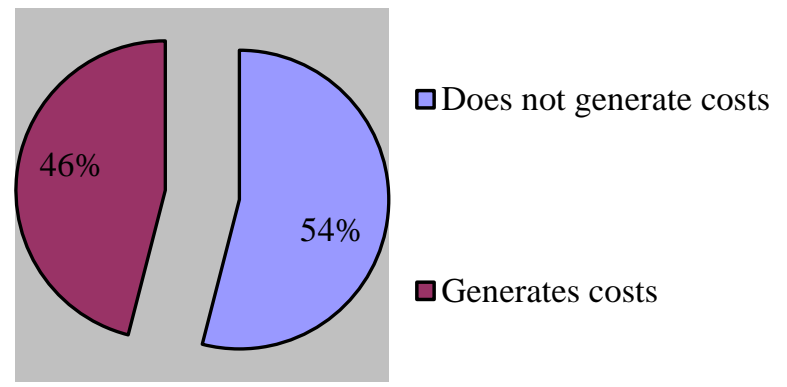

Graphic 8 Percentage of companies that generate costs return damaged raw material

$23 \%$ said that these companies have some kind of inspection in their packaging, while $77 \%$ do not.

In Rincon de Romos, $8 \%$ have a check list or verification sheets to know the conditions of their products, while $92 \%$ do not have it.

In these companies, $77 \%$ of them carry out the evaluation of the product before going on the market, while $8 \%$ seek to implement this process, $15 \%$ of them do not have the procedure.

Of these companies, $31 \%$ said they have communication between the client and the supplier to establish the conditions of the product before it reaches the company, while $8 \%$ seek to implement it and $62 \%$ do not count on it.

In this aspect, it was evaluated if the companies carried out some type of inspection in the prototypes they made, $15 \%$ said yes, while $85 \%$ said no.

$8 \%$ perform product audits, however $92 \%$ do not carry it out.
While $15 \%$ carries out audits of the process and the remaining $85 \%$ does not carry it out.

In addition, $8 \%$ carry out customer service audits, while $92 \%$ do not.

Another aspect evaluated was if there are calibration systems for measuring equipment, $15 \%$ said yes, while $85 \%$ said no.

In addition, $8 \%$ of these companies have a test equipment calibration system, while $92 \%$ do not have it.

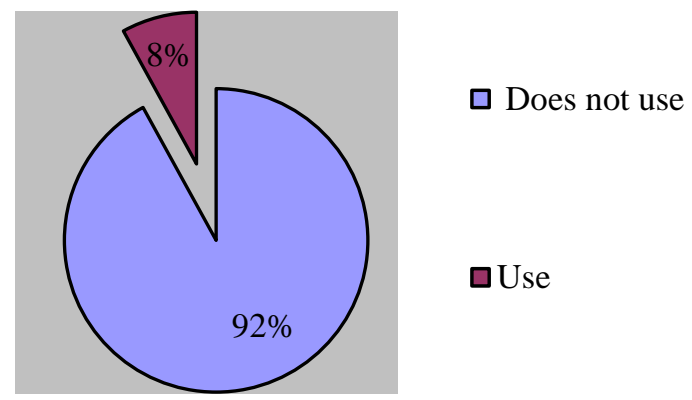

Graphic 9 Use of test calibration equipment

\section{Costos de falla interna}

In Rincon de Romos these companies said that in $31 \%$ of these companies have some type of waste that generates cost and $69 \%$ say otherwise. On the other hand, $46 \%$ said they had re-work, $23 \%$ said they were looking for a process to do re-jobs and $31 \%$ said they did not have rework.

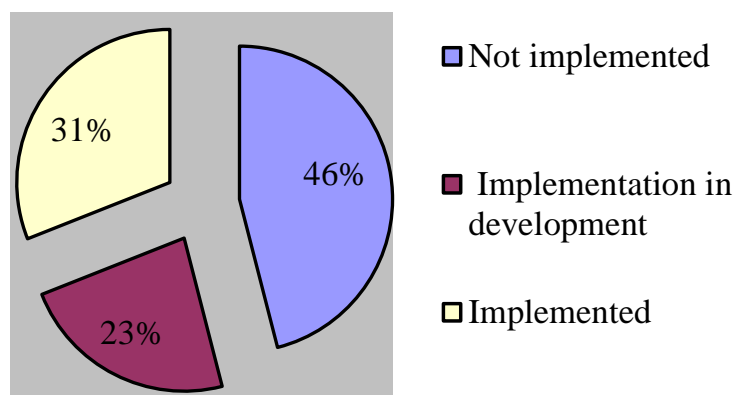

Graphic 10 Companies with re-work.

Of the companies consulted, 54\% said they had re-inspections and $45 \%$ said they did not have re-inspections.

In addition, $8 \%$ of the companies consulted perform repairs internally and $92 \%$ do not have these procedures. 


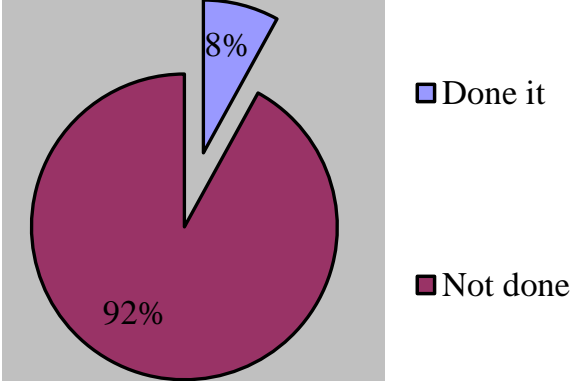

Graphic 11 Companies that carry out repairs internally

\section{External failures costs}

In the companies consulted $23 \%$ of these have a system within the company that regulates the returns and / or tolerances of the product, while $77 \%$ do not count on it.

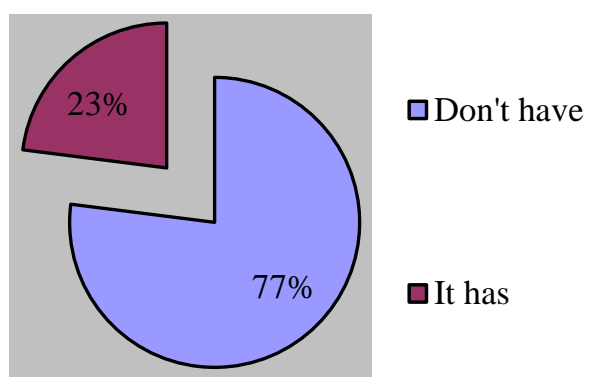

Graphic 12 Companies that have a system regulates the returns and / or tolerances of the product

Of these companies, $54 \%$ offer discounts to customers, while $23 \%$ do not carry it out and the other $23 \%$ seek to implement it.

$85 \%$ of the companies said they were responsible for the product at the time of delivery, while $15 \%$ is not. Regarding the area of having a complaints department, these companies have an $8 \%$ with it, while $85 \%$ of them do not count on it and $7 \%$ seek to implement it.

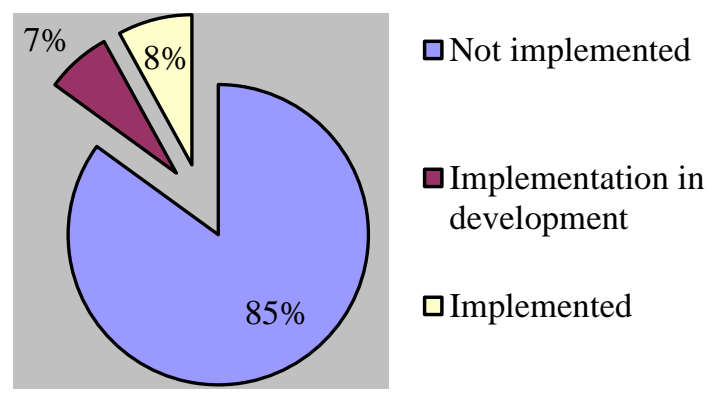

Graphic 13 Complaints Department

Of these companies, $54 \%$ of companies have a defective product recovery process, while $46 \%$ do not count on it.
The companies consulted said that $46 \%$ generated some type of cost to recover the defective product, and $54 \%$ said no.

In Rincon de Romos the companies interviewed perform the corresponding tasks against the ill will that there is in the company in $62 \%$, while the remaining $38 \%$ do not count on it.

$31 \%$ have training to improve the work environment, while $69 \%$ do not have it.

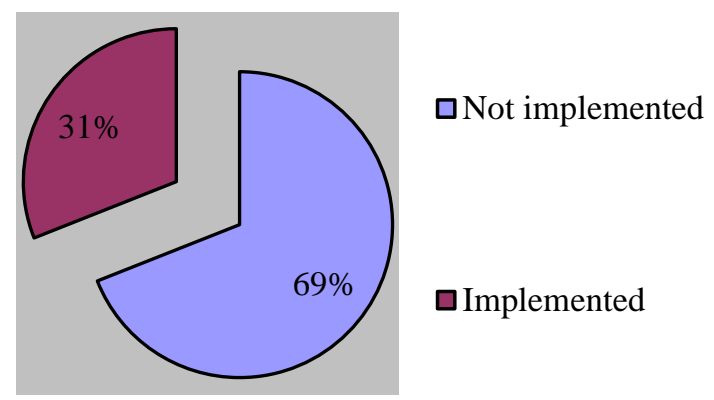

Graphic 14 Trainings to improve the Labor Climate

\section{Process management}

In the area of process management, the Rincon de Romo companies define documents by $8 \%$ and establish responsibilities for the processes that make up the value chain, while $92 \%$ do not. $92 \%$ of the companies consulted maintain a system of indicators and process metrics with their corresponding competitive references, while $8 \%$ do not have it.

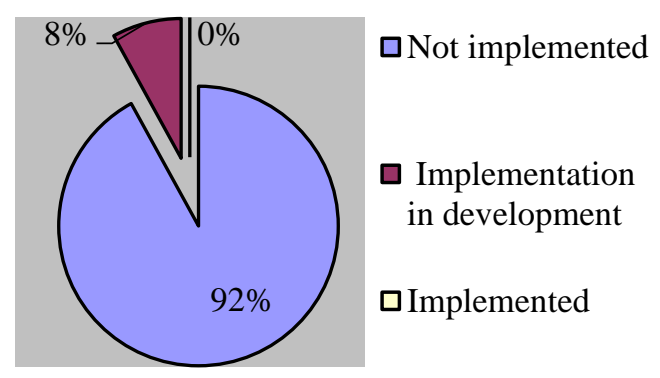

Graphic 15 System of indicators and process metrics

$62 \%$ of the companies analyzed in Rincon de Romos, these companies consider the requirements of customers and the market in the design of their processes, while $38 \%$ of them do not.

$31 \%$ of companies establish standards and indicators of the quality of their processes, while $69 \%$ do not.

VAZQUEZ-GUTIERREZ, Rosa Inés, FLORES-AGUILAR, Mauricio y NÚNEZE-MONTALVO, Juan Manuel. Impact of the Quality Costs applied in Automotive and Metal-Mechanical Manufacturing SMEs in the North of Aguascalientes. Municipality of Rincon de Romos. Journal of Quantitative and Statistical Analysis. 2019 
Companies develop their established suppliers by monitoring quality indicators for specific processes by $8 \%$, while $92 \%$ do not.

\section{Conclusions}

The companies consulted in Rincon de Romos need to cement the structure of the leadership field because a high percentage do not have the mission, vision and policies well, and they must also define the necessary policies to move from an autocratic leadership to a participatory one.

In strategic planning they do not have the adequate planning to create a more competitive scenario and this can lead them to close because they are not considering the long-term expectations of the clients.

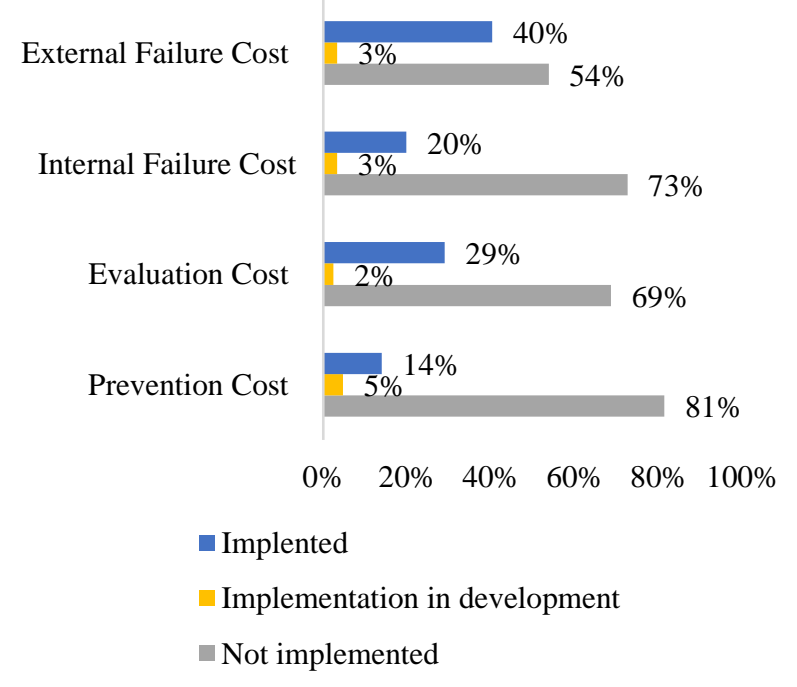

Graphic 16 Quality Cost in Rincon de Romos

In this graph we can see that there is an implementation of the tools of external failure costs by $40 \%$, as tools of internal failure costs by $20 \%$, on tools of evaluation costs by $29 \%$ and $14 \%$ on costs of prevention, for this reason we can observe:

When companies show deficiencies in the implementation of leadership, they put their permanence and competitiveness at risk in the industrial sphere, because they can not maintain the commitment and loyalty of their associates.

The lack of planning of the companies, can limit their development as well as the diversification of their products and services according to the needs of their clients.
At the point of people management, companies must put more emphasis on the selection, as well as on the training of people, since the tendency in companies is to continuous improvement and without trained human capital, companies They will see more limited and less competitive.

At the point of evaluation costs, companies need to involve their suppliers more in order to prevent at source the failures of the services and products they provide to their final customers, which will reduce the quality costs for both companies as for suppliers and customers.

It is important to consider in the same way that the companies in question of process management have to start improving their control of documents and at the same time set responsibilities on the processes that make up the value chain since most of them do not and this to the long causes more serious problems in their processes.

It is also very important to mention that in this investigation it was detected that most of the companies do not have a quality standardization control or apply quality indicators that allow them to know how their processes are behaving, this part is very fundamental that by not knowing their indicators or quality standards there is a risk of high costs due to poor quality. Companies not knowing their quality standards or quality indicators are not in a position to monitor the indicators of the processes handled by their suppliers, which in this investigation was a very significant result and which argues even more than the cost per poor quality are higher by not having these procedures to ensure the total quality in the production processes handled by the companies studied

\section{Recommendations}

First of all, it is necessary that these companies establish the mission, vision and quality objectives so that the company has a clear vision of what its objective is. In the same way, it is necessary to establish a strategic planning that guarantees them to remain in the market. Likewise, it is necessary to make a good selection of your personnel, train them and find a way to feel the need to belong.

VAZQUEZ-GUTIERREZ, Rosa Inés, FLORES-AGUILAR, Mauricio y NÚÑEZ-MONTALVO, Juan Manuel. Impact of the Quality Costs applied in Automotive and Metal-Mechanical Manufacturing SMEs in the North of Aguascalientes. Municipality of Rincon de Romos. Journal of Quantitative and Statistical Analysis. 2019 
The companies of this region are recommended to use at least the basic tools of quality as well as to implement the bases of a quality system to have their processes documented and this allows them to guarantee the quality of their products, continue with the knowledge of the elaboration of the same ones and to use the documents of quality so that they can train the personnel that work with them in a future with the purpose of avoiding the backward movement in the elaboration of their products.

Similarly, it is recommended that companies perform monthly or quarterly evaluations of their quality indicators of both their processes and that of their suppliers so that the correct execution of the quality tools that are implemented is guaranteed and thus continue with the continuous improvement that every organization must maintain to be able to survive in a globalized business world where the failure to carry out a good quality deployment can be the guideline to follow or not in the competitive market of each of the items to which belongs to each of the organizations studied in this research.

It is recommended that companies perform the application of basic quality tools, for which companies must work hard in their correct application and training from this study which has been very useful for all organizations surveyed.

\section{References}

Aburto Jiménez, Manuel. Administración por calidad México: CECSA, 1997 c1992

Ads Quality. Enciclopedia de la Calidad. España: 2002

Blanco Llano, Francisco Javier. Diseño de procesos claves para el mejoramiento de la calidad.La Habana : Instituto Superior Politécnico José Antonio Echeverría. CUJAE, 2010

Del Río, González. Costos 1. México: ECAFSA, 1998.

Del Río, González Costos 3 . México: ECAFSA, 1999.
Cantú Delgado, Humberto. Desarrollo de una cultura de calidad México, D.F.: McGrawHill/Interamericana, 2011

Crosby, Philip B. La calidad no cuesta: el arte de cerciorarse México: CECSA, 1987

Crosby, Philip B . Calidad sin lágrimas. México: Continental. (2000).

Deming, W. Edwards Calidad, productividad y competitividad: la salida de la crisis Madrid: Ediciones Díaz de Santos, c1989.

Don R. Hansen. Maryanne M. Mowen. Administración de costos, contabilidad y control. México D.F., Thomson, (2003).

Evans, Jame. Lindsay, William. Administración y control de la calidad. México: 2005. Thomson.

Gutiérrez Pulido, Humberto. Calidad Total y Productividad México, D.F.: McGraw-Hill Education, 2010.

Gutiérrez Pulido, Humberto. Control estadístico de la calidad y seis sigma México, D.F.: McGraw-Hill Education, 2013.

Harrington, H. J. Mejoramiento de los procesos de la empresa. Colombia: 1998. McGraw-Hill

Hernández Sampieri, Roberto. Metodología de la investigación México, D.F.: McGraw-Hill, 2010.

INEGI, Directorio Estadístico Nacional de Unidades Económicas (DENUE), año 2016.

Instituto Mexicano de Normalización y Certificación, Sistemas de gestión de la calidadrequisitos (ISO 9001:2008) México: IMNC, 2008

Ripoll, V., \& Balada, T.. (2005). Información de costes para la toma de decisiones empresariales. España: Rotapapel.

Valdes. La sexta generación de los procesos de calidad. Buenos Aires (Argentina) : El Cid Editor, 2009 